\title{
„NEC TEMERE NEQUE INIUSTE, SED CONSULTO ET AEQUITATIS DUCTU IN HANC TERRAM TRANSVECTUS SUM" (GG II, 12) - LEGITYMIZOWANIE WLADZY W GESTA GUILLELMI WILHELMA Z POITIERS
}

\section{Wprowadzenie}

Historyk przystępujący do prezentowania badań dotyczących postaci Wilhelma Zdobywcy jest zobowiązany skrupulatnie uzasadnić, dlaczego postanowił podjąć pracę nad tak popularnym i często poruszanym tematem ${ }^{\mathrm{I}}$. Problematyka normańskiego podboju Anglii i objęcia tamtejszego tronu przez Zdobywcę w Io66 r. jest jednym z najczęściej przywoływanych, opisywanych i dyskutowanych wydarzeń. Często wydawane są biografie Wilhelma o charakterze naukowym bądź popularyzatorskim². Bogata jest również literatura na temat normańskiego podboju Anglii, podłoża tego zjawiska, jego przyczyn i skutków³.

W niniejszym artykule pragnę skupić się na pierwszej biografii zwycięzcy spod Hastings, spisanej jeszcze za życia Wilhelma, w kilka lat po objęciu władzy w Anglii. Jej autorem jest Wilhelm z Poitiers, duchowny związany z dworem Zdobywcy. Pośród utworów opisujących normański podbój Anglii Gesta Guillelmi zajmują miejsce szczególne, wyróżniają się bowiem konsekwentnie panegirycznym i legitymizacyjnym ukierunkowaniem narracji ${ }^{4}$. Sam autor w ten sposób opisał główny cel powstania utworu:

\footnotetext{
1 Pragnę w tym miejscu wyrazić wdzięczność Uniwersytetowi Kardynała Stefana Wyszyńskiego w Warszawie, mojej Alma Mater, za pokrycie kosztów kwerendy naukowej, która umożliwiła mi podjęcie pracy nad niniejszym artykułem.

2 Na przykład: jedna z najnowszych - M. Hagger, William. King and Conqueror, New York 2012; jedna z najbardziej znanych: D.C. Douglas, William the Conqueror, London 1969; wydane w Polsce - P. Zumthor, Wilhelm Zdobywca, Warszawa 1994; D. Bates, Wilhelm Zdobywca, Warszawa 2007.

3 Najbardziej aktualna monografia normańskiego podboju Anglii - G. Garnett, Conquered England. Kingship, Succesion, and Tenure, 1066-1166, Oxford 2007 [dalej jako: Garnett, Conquered England]; ze starszych na przykład: P. Stafford, Unification and Conquest. A Political and Social History of England in the Tenth and Eleventh Centuries, London 1989; najnowsza praca o nieco bardziej popularnym charakterze - M. Morris, The Norman Conquest: The Battle of Hastings and the Fall of Anglo-Saxon England, New York-London 2013; wydana niedawno w Polsce - N.J. Higham, Podbój Anglii przez Normanów, Warszawa 2001; starsza, ale wciąż warta uwagi praca pokazująca sukces Wilhelma Zdobywcy w kontekście działań Normanów w innych miejscach Europy - R.A. Brown, Historia Normanów, Gdańsk 1996.

4 Niektórzy historycy określają Gesta Guillelmi jako dzieło o charakterze panegirycznym. Patrz w szczególności: E. Abu, The Normans in their Histories: Propaganda, Myth and Subversion, Woodbridge 2001, s. 2, 81-82, [dalej jako: Abu, The Normans in their Histories]. Jednak tego słowa nie używa autor najważniejszego artykułu nauko-
} 
Quapropter nos operae pretium arbitramur quam verissime tradere quatinus Guillelmus hic (quem scripto propagamus, quem tam futuris quam praesentibus in nullo displicere, immo cunctis placere, optamus) Cenomanico principatu, quemadmodum regno Anglico, non solum forti manu potitus fuerit, sed et iustitiae legibus potiri debuerit ${ }^{5}$.

Słowa te zostały umieszczone pod koniec pierwszej z dwóch ksiąg dzieła, zamykają one wstępną część opowiadania o czynach Wilhelma. Trzynaście następnych rozdziałów dotyczy opanowania Maine, po czym autor przechodzi do głównego wątku - walki o objęcie władzy w Anglii. W przytoczonym fragmencie Wilhelm z Poitiers zwraca się wprost do odbiorcy i zapowiada, że opowie o tym, jak zostało zdobyte księstwo Maine oraz królestwo Anglii oraz dodaje, że wyjaśni, dlaczego Wilhelm był prawowitym władcą tamtych ziem. Celem autora nie jest więc jedynie opisanie wojennych sukcesów głównego bohatera narracji. Wilhelm z Poitiers pisał po to, aby uzasadnić słuszność roszczeń księcia Normandii do tronu Anglii, chciał scharakteryzować podstawę ideową rządów normańskich w Londynie, chciał pokazać, że Wilhelm nie jest jedynie Zdobywcą - kimś, kto panuje wyłącznie dzięki sile swej armii. W skonstruowanym przez niego obrazie dziejów Wilhelm Zdobywca jest jedynym sukcesorem Edwarda Wyznawcy, nie jest zdobywcą, lecz władcą Anglii, który przybywa, by zasiąść na przyrzeczonym sobie tronie, a ponadto monarchą realizującym chrześcijański ideał władcy ${ }^{6}$.

Gesta Guillelmi wydają się być wartościowym źródłem dla zbadania problemu legitymizowania władzy w średniowiecznych źródłach narracyjnych. Pomiędzy źródłami opowiadającymi o Zdobywcy i prezentującymi normański punkt widzenia dzieło Wilhelma z Poitiers wyróżnia się konsekwentnie pochwalnym charakterem, jednolitością tematyczną oraz tym, że autor był blisko opisywanych wydarzeń i pisał krótko po bitwie pod Hastings? Choć Gesta Guillelmi były obiektem zainteresowania historyków, to nie powstała praca, która skupiałaby się na obserwacji i analizie argumentów uzasadniających władzę Zdobywcy ${ }^{8}$.

wego o Wilhelmie z Poitiers: R.H.C. Davis, William of Poitiers and his History of William the Conqueror, w: The Writing of History in the Middle Ages, essays presented to Richard William Southern, red. R.H.C. Davis, J.M. Wallace-Hadrill, Oxford 1981, s. 71-100, [dalej jako: Davis, William of Poitiers]; jak również autorka wprowadzenia do najnowszej edycji dzieła: M. Chibnall, Introduction, w: The Gesta Guillelmi of William of Poitiers, ed. i tłum. R.H.C. Davis, M. Chibnall, Oxford 1998, s. xv-xlvii, [dalej jako: GG].

5 GG I, 36, s. 58.

6 Historycy są zgodni co do tego, że najważniejszym motywem napisania Gesta Guillelmi była potrzeba uzasadnienia objęcia tronu angielskiego przez Wilhelma Zdobywcę: GG, s. xx; R.H.C. Davis, William of Poitiers, s. 74; D. Bates, The Conqueror's Earliest Historians and the Writing of his Biography, w: Writing medieval biography 750-1250. Essays in honour of professor Frank Barlow, red. D. Bates, J. Crick, S. Hamilton, Woodbrigde 2006, s. 130, [dalej: Bates]; G. Garnett, Conquered England, s. 40; E. van Houts, The Memory of 1066 in Written and Oral Tradition, „Anglo-Norman Studies”, 19/1997, red. Ch. Harper-Bill, Woodbridge 1997, s. 167-179.

7 Pozostałe źródła „normańskie”: The Carmen de Hastingae Proelio of Guy Bishop of Amiens, ed. C. Morton, H. Muntz, Oxford 1972; The 'Gesta Normannorum Ducum' of William of Jumieges, Orderic Vitalis, and Robert of Torigni, ed. E.M.C. van Houts, 2 tomy, Oxford 1992-1995; The Ecclesiastical History of Orderic Vitalis, ed. M. Chibnall, 6 tomów, Oxford 1969-1980. Na temat normańskiego piśmiennictwa historycznego patrz również: L. Shopkow, History and Community: Norman Historical Writing in the Eleventh and Twelfth Centuries, Washington 1997; oraz Abu, The Normans in their Histories.

8 Pobieżne streszczenie argumentacji: GG, s. xxvi; Abu, The Normans in their Histories, s. 84-85; N. Marafioti, The King 's Body. Burial and Succesion in Late Anglo-Saxon England, Toronto 2014, s. 113 [dalej jako: Marafioti, The King's Body]. Autorzy wymienionych prac ograniczają się do wypunktowania poszczególnych argumentów, jedynie N. Marafioti odnosi się szerzej do pochówku Harolda i koronacji Wilhelma. 
Zapoznanie się z treścią i charakterem tego dzieła oraz poznanie literatury naukowej związanej z normańskim podbojem Anglii zaowocowało wnioskiem, iż warto byłoby dokładniej niż to było dotychczas czynione przeanalizować Gesta Guillelmi skupiając się na argumentacji, jakiej używa ich autor do uzasadniania legalności władzy księcia Normandii w Londynie. W niniejszym tekście pragnę zaprezentować moje badania nad tym, w jaki sposób Wilhelm z Poitiers legitymizował objęcie władzy w Anglii przez Wilhelma Zdobywcę w biograficznym dziele Gesta Guillelmi.

Dla elity normańskiej uzasadnienie dokonanego podboju było niezwykle istotne dla skutecznego sprawowania rządów na opanowanych terenach. Poprzez pokazanie, że nie był to zwykły najazd, ale słuszne, na płaszczyźnie moralnej i prawnej, objęcie władzy, Wilhelm Zdobywca i jego otoczenie dążyli do utrwalenia swego panowania. W Io66 roku atak obcej armii doprowadził do obalenia namaszczonego i koronowanego króla Anglii ${ }^{9}$. Jego ciało nie zostało pochowane jak ciało monarchy, ale złożono je w bezimiennym grobie na niepoświęconej ziemi. Widać wyraźnie, że Wilhelm Zdobywca dążył do tego, aby być zwycięzcą także na płaszczyźnie ideowej, co wymagało deprecjonowania autorytetu króla Harolda Godwinsona ${ }^{\mathrm{ID}}$. Koronacja Harolda w styczniu io66 r. była wydarzeniem o wielkim znaczeniu dla Anglii i większość elity angielskiej uznawała ją wówczas za prawowitą ${ }^{\text {II }}$. Dlatego dziejopisarz tworzący w kręgu normańskim, który stanął przed wyzwaniem stworzenia opowieści o życiu Wilhelma Zdobywcy, widział jako jedno z najważniejszych zadań, aby pokazać słuszność roszczeń księcia Normandii do tronu Anglii oraz to, że nie był on zewnętrznym agresorem, ale prawowitym władcą, który upomniał się o należny jemu tron.

Celem moich badań nad Gesta Guillelmi była obserwacja tego, jak Wilhelm z Poitiers poradził sobie z zadaniem legitymizacji władzy Wilhelma Zdobywcy w Anglii. Ważnym pytaniem dla mnie było, do jakiego stopnia opowieść o życiu Zdobywcy i jego podbojach była konstruowana pod kątem potrzeby udowadniania ich słuszności moralnej i prawnej. Za ważne zadanie uważałem wyodrębnienie takich miejsc w narracji, które są bezpośrednio związane z tematem legitymizacji władzy. Należało oddzielić tę płaszczyznę od innych, na które wkraczał autor tworząc tekst. Na przykład podkreślanie zalet Wilhelma Zdobywcy nie musiało, ale mogło łączyć się z uzasadnianiem objęcia przez niego tronu Anglii. Jednak analizując Gesta Guillelmi dostrzegłem, iż potrzeba legitymizowania władzy była na tyle duża, że autor wielokrotnie i na różne sposoby tak kształtował narrację, aby pokazać Zdobywcę jako prawowitego następcę Edwarda Wyznawcy. W jaki sposób Wilhelm z Poitiers uzasadniał wstąpienie Wilhelma Zdobywcy na tron w Londynie i w jaki sposób delegitymizował władzę Harolda Godwinsona? Do jakich argumentów się odwoływał? Jakich używał do tego środków? Celem powstania niniejszego artykułu było zaprezentowanie odpowiedzi na te pytania i podzielenie się wnioskami płynącymi z badań nad przedstawioną problematyką.

\footnotetext{
$9 \quad$ Fakt ten, pisząc o dziele Wilhelma z Poitiers, mocno akcentuje Bates, s. 130-131. Podzielam przekonanie, iż obalenie przemocą namaszczonego monarchy było wydarzeniem w pewnym sensie wstrząsającym dla ówczesnych elit politycznych.

10 Na temat roli jego i jego rodu w czasie panowania Edwarda Wyznawcy, a także postawy wobec sukcesji normańskiej w Anglii: M.W. Campbell, Earl Godwin of Wessex and Edward the Confessor's Promise of the Throne to William of Normandy, „Traditio”, 28/1972, s. 141-158.

11 Podążam w tym miejscu za wywodem Marafioti, The King's Body, s. 119.
} 


\section{Autor i dzieło}

Jeszcze przed zagłębieniem się w treść należy podjąć próbę podsumowania dotychczasowej wiedzy o autorze i o samym dziele ${ }^{\mathrm{I}}$. Jedynym źródłem informacji na temat życia Wilhelma z Poitiers jest Historia Ecclesiastica, spisana w pierwszej połowie XII w. w Normandii ${ }^{13}$. Jej autor, Orderyk Vitalis, korzystający z Gesta Guillelmi, podaje, że autor pierwszej biografii Zdobywcy urodził się w Preaux, w Normandii, zapewne w trzecim dziesięcioleciu XI w., w raczej zamożnej i znaczącej rodzinie, ponieważ jego siostra została przeoryszą jednego z miejscowych klasztorów żeńskich. Pierwotnie przygotowywany do stanu rycerskiego, został ostatecznie duchownym. Kształcił się w Poitiers, o czym sam wspomniał na kartach dzieła - od miejsca nauki wziął się jego przydomek ${ }^{14}$. Odebrał tam gruntowne, jak na owe czasy, wykształcenie, by po kilku latach powrócić do Normandii w pierwszej połowie lat pięćdziesiątych. Tam jako młody duchowny z możnej rodziny z ponadprzeciętnymi zdolnościami intelektualnymi i wykształceniem został, wedle Orderyka Vitalisa, kapelanem księcia Wilhelma. Problemem dla historyków jest fakt jego niewystępowania w charakterze świadka w dokumentach wydawanych przez Wilhelma Zdobywcę, dlatego też nic nie wiadomo o roli, jaką odgrywał w otoczeniu władcy. Pewne poszlaki wskazują, że w późniejszym okresie, w ósmej dekadzie XII w., Wilhelm z Poitiers pełnił funkcję archidiakona w Lisieux, będąc w bliskim kontakcie z wpływowym biskupem Odonem, który w I077 r. był jednym $z$ inicjatorów buntu przeciwko Zdobywcy, buntu, który, jak się przypuszcza, mógł doprowadzić do zatrzymania pracy nad Gesta Guillelmi.

To właśnie wówczas, zgodnie z dość wymijającymi słowami Orderyka, Wilhelm z Poitiers został zmuszony przez pewne niefortunne okoliczności do zaprzestania tworzenia biografii Zdobywcy ${ }^{15}$. Dzieło powstawało pomiędzy rokiem I07I a $1077^{16}$. Gesta Guillelmi uznawane jest za dzieło wyróżniające się pod względem formy literackiej. Autor świadomie posługuje się różnymi stylami, zbliżając się do św. Augustyna lub Cycerona przy rozważaniach moralnych oraz do stylu Salustiusza i Juliusza Cezara przy opisywaniu zmagań wojennych. Dostrzegalna jest znajomość Eneidy oraz dzieł Juwenalisa, Tacyta, Swetoniusza i innych, a także łacińskiej wersji Iliady ${ }^{17}$. Co więcej, autor często mocno podkreśla i rozbudowuje nawiązania do literatury antycznej wyraźnie uznając to za nieodzowny element narracji ${ }^{18}$, przy czym ani nie cytuje Biblii, ani nie włącza do tekstu motywów biblijnych ${ }^{19}$.

12 Korzystałem głównie z: GG, s. xv-xix; Davis, William of Poitiers, s. 84-91.

13 Najnowsze wydanie: The Ecclesiastical History of Orderic Vitalis, ed. M. Chibnall, 6 tomów, Oxford 19691980 [dalej jako: OV].

14 GG I, 11, s. 14: dum Pictavis exularem.

15 OV II, s. 184: adversis casibus impeditus. Cytat za: Davis, William of Poitiers, s. 84.

16 Przekonująco na ten temat: Davis, William of Poitiers, s. 74.

17 GG, 18; Davis, William of Poitiers, s. 72; szerzej na temat m.in.: J.R.E. Bliese, Leadership, Rhetoric, and Morale in the Norman Conquest of England, „Military Affairs”, t. 52, 1/1988, s. 23-28; J. Rubenstein, William of Poitiers Talks about War, w: The Middle Ages in Texts and Texture, Toronto 2011, s. 129-140.

18 Istotnym elementem charakterystyki Wilhelma i jego angielskiego panowania jest porównanie do Juliusza Cezara, które Wilhelm z Poitiers szeroko wykorzystuje, podsumowując całość narracji, vide: GG II, 32, 39-40.

19 Poziom znajomości literatury antycznej i stosunek autora do auctores wydają się być interesującym problemem badawczym. Obserwacje na tym polu mogą być szczególnie interesujące, jeśli wpisać Wilhelma z Poitiers w kontekst jedenastowiecznej literatury. 
Przy tworzeniu opowieści o życiu Zdobywcy Wilhelm z Poitiers korzystał z normandz-

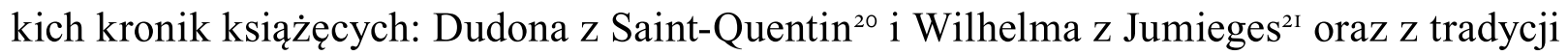
ustnej. Najprawdopodobniej czerpał on informacje z wymienionych źródeł głównie do opisu wydarzeń we wczesnym okresie panowania Zdobywcy, potem był w bezpośrednim otoczeniu władcy, więc z bliska widział zarówno okres poprzedzający inwazję na Anglię, jak i rok Io66, a także dalsze dzieje. Podobieństwa pomiędzy Gesta Guillelmi a Gesta Normannorum Ducum i innymi współczesnymi źródłami powstałymi w kręgu normandzkim, czyli Carmen de Hastingae Proelio ${ }^{22}$ i tkaniną $\mathrm{z}$ Bayeux ${ }^{23}$, wynikają $\mathrm{z}$ opierania się na tożsamej tradycji ustnej i wizji tych wydarzeń funkcjonujących na dworach władców normańskich oraz tamtejszych możnowładców ${ }^{24}$.

Dzieło Wilhelma z Poitiers nie było w późniejszym czasie wykorzystywane. Czynili to jedynie piszący nie więcej niż kilkadziesiąt lat później Orderyk Vitalis, Robert z Torigni, Wilhelm z Malmesbury oraz kilku innych mniej znanych autorów. Gesta Guillelmi nie stały się dla przyszłych pokoleń opowieścią o Wilhelmie Zdobywcy, dzieło to praktycznie nie było znane, tę rolę pełniły Gesta Normannorum Ducum. Świadczy o tym liczba kopii rękopiśmiennych, gdyż to drugie dzieło zachowało się do dzisiaj w 43 manuskryptach, podczas gdy nie jest znany ani jeden rękopis Gesta Guillelmi. Prawdopodobnie istniały dwa rękopisy, jeden z nich znany był kronikarzom działającym w Anglii, drugi obecny był w Normandii. Żaden $\mathrm{z}$ nich nie jest odnaleziony, ślad ich istnienia widać jedynie w korespondencji pewnych uczonych w XVII w., którzy interesowali się tym dziełem²5. Współczesna nauka zawdzięcza dostęp do tekstu dzieła Wilhelma z Poitiers siedemnastowiecznej edycji Andre Duchesne'a ${ }^{26}$, która była podstawą wszystkich późniejszych wydań.

Gesta Guillelmi nie weszły do obiegu intelektualnego ani w XI w., ani w czasach późniejszych. Mimo to Wilhelm z Poitiers jest reprezentatywnym przedstawicielem kultury umysłowej drugiej połowy XI w., jego dzieło zaś jest podobne do ówczesnych biografii królewskich, czego nie zmieniają wszelkie odrębności. Z tego punktu widzenia badania nad Gesta Guillelmi dają możliwość wglądu w kulturę i literaturę oraz w szeroko rozumianą myśl polityczną XI w.

Wykorzystywana do pracy nad niniejszym artykułem edycja krytyczna dzieła Wilhelma z Poitiers dzieli je na dwie księgi, z których pierwsza zawiera 59, a druga 49 rozdziałów. Tego podziału, który został utrzymany w najnowszej edycji, dokonała autorka pierwszej

\footnotetext{
20 De moribus et actis primorum Normanniae ducum auctore Dudone Sancti Quintini decano, ed. J. Lair, Caen 1865.

21 The 'Gesta Normannorum Ducum' of William of Jumieges, Orderic Vitalis, and Robert of Torigni, ed. E.M.C. van Houts, 2 tomy, Oxford 1992-1995.

22 The Carmen de Hastingae Proelio of Guy Bishop of Amiens, ed. C. Morton, H. Muntz, Oxford 1972.

23 The Bayeux Tapestry, ed. F.M. Stenton, London 1957.

24 W ten sposób o tym zagadnieniu: GG, s. xxvii, xxviii.

25 Referowanie ustaleń R.H.C. Davisa i M. Chibnall nie jest w tym miejscu konieczne, zainteresowanych należy odesłać do GG, s. xliii-xlv, gdzie zostały wyłożone wyniki kwerend archiwalnych.

26 Historiae Normannorum scriptores antiqui, ed. A. Duchesne, Paris 1619, s. 178-213. Duchesne korzystał z manuskryptu przechowywanego w bibliotece sir Roberta Cottona, zmarłego w 1631 angielskiego bibliofila i antykwariusza. Tekst z edycji Duchesne'a został wydany ponownie w: J.P. Migne, Patrologia Latina, t. 149 , kol. 1217-1270; pierwsza współczesna edycja krytyczna: R. Foreville, Guillaume de Poitiers, Histoire de Guillaume le Conquerant, Paris 1952; w pracy nad tym artykułem była wykorzystywana najnowsza edycja wydana w $1998 \mathrm{r}$. w Oksfordzie, w serii Oxford Medieval Texts, oznaczona jako GG. Pełny wykaz edycji Gesta Guillelmi w: GG, s. XLV-XLVI.
} 
współczesnej edycji krytycznej, Raymond Foreville. Editio prima Andre Duchesne’a nie wprowadzała żadnego podziału wewnątrz tekstu ${ }^{27}$, ponadto rękopis, z którego korzystał Duchesne, nie miał początku ani zakończenia. Zachowany tekst zaczyna się passusem, który jest poświęcony śmierci Kanuta w IO35 r. i sukcesji tronu angielskiego. Od I, 6 autor przechodzi do opowiadania o tym, w jaki sposób Wilhelm podporządkował sobie Normandię i walczył z wrogami zewnętrznymi, choć w pewnych miejscach skupia się na sytuacji w Anglii. Od I, 4I uwaga autora koncentruje się niemal wyłącznie na podboju Anglii i nie zmienia się to aż do II, 30, gdzie jest opisana koronacja Wilhelma w Londynie. Kolejne siedem rozdziałów opowiada o przejmowaniu władzy nad Anglią, po czym w II, 38 Zdobywca wraca do Normandii. Kolejne jedenaście rozdziałów opisuje uroczystości z okazji powrotu władcy i wewnętrze sprawy Normandii. Tematem ostatnich rozdziałów są Anglicy wspierający władzę Wilhelma w Anglii, jednak tekst urywa się, gdy autor zaczyna opowieść o Ealdredzie, arcybiskupie Jorku, który miał z zapałem wspierać Zdobywcę.

Z krótkiego podsumowania treści wynika, że najważniejszą częścią dzieła z punktu widzenia założonego celu pracy jest przestrzeń od I, 4I do II, 30, jednak poza opowieścią o wydarzeniach roku Io66 Wilhelm z Poitiers w różny sposób budował także uzasadnienia ideowe władzy Zdobywcy. Szczególnie ważne są te passusy, które dotyczą Edwarda Wyznawcy, jego wstąpienia na tron i panowania w Anglii - to od nich rozpocznie się analiza narracji Wilhelma z Poitiers.

\section{Początek opowieści}

Po śmierci Kanuta Wielkiego w I035 r. władzę w Anglii objął jego syn Harold Zajęcza Stopa, którego matką była pierwsza żona Kanuta, Elgifu z Northampton. Kanut był pierwszym koronowanym władcą Anglii, który najechał ten kraj z zewnątrz i przemocą przejął władzę. Zdołał zaprowadzić na tyle silne rządy, że zapewnił sukcesję swoim synom. Obaj synowie Kanuta, Harold Zajęcza Stopa, a następnie Harthakanut, syn z drugiego małżeństwa z Emmą - normańską księżniczką i wdową po Ethelredzie II, zmarli bezpotomnie po kilku latach rządów. W I043 r., po trwającym prawie 30 lat skandynawskim panowaniu w Anglii, królem został Edward Wyznawca, syn Ethelreda II, ostatniego króla z dynastii anglosaskiej i wspomnianej Emmy. Jego panowanie trwało do I066 r., a bezpotomna śmierć otworzyła drogę do walki o władzę.

W pierwszym zachowanym rozdziale Wilhelm z Poitiers kreśli obraz sytuacji politycznej w Anglii w momencie śmierci Kanuta w I035 r. Wydaje się bardzo prawdopodobne, że wśród angielskich elit doświadczenie normańskiego podboju było porównywane z najbliższym podobnym wydarzeniem, jakim było objęcie władzy przez Kanuta, które miało miejsce na pół wieku przed Wilhelmem Zdobywcą. Dwór księcia Normandii obawiał się takich porównań i starano się kształtować obraz władzy w opozycji do władców skandynawskich. Autor biografii Zdobywcy już w pierwszych słowach wypowiada się na temat Kanuta i Harolda Zajęcza Stopa. W tym przekazie Kanut panował w Anglii wyłącznie dzięki przemocy swojej i swego ojca, a jego syn był niegodny tronu, ponieważ był tyranem ${ }^{28}$. Już w następnym

$27 \mathrm{Z}$ wyjątkiem umieszczenia słów sygnalizujących początek opisu bitwy pod Hastings na poczatku II, 9 wedle edycji Foreville. M. Chibnall przypuszcza, że w tym miejscu kończyła się pierwsza część rękopiśmiennej wersji dzieła.

28 GG I, 1, s. 2. 
zdaniu autor pokazuje, że prawowitymi dziedzicami tronu angielskiego są synowie Emmy i Ethelreda, który zostaje nazwany słowami rex Anglorum - nie określono zaś w ten sposób ani Kanuta, ani jego synów. Wilhelm z Poitiers opowiada, że Edward i Alfred, synowie Etherleda, musieli uciekać $\mathrm{z}$ kraju, gdyż w przeciwnym wypadku zostaliby zamordowani przez Duńczyków, którzy okupowali ich królestwo. Schronili się na dworze książąt Normandii, skąd wywodziła się ich matka. Zostaje podkreślone, że pomocy udzielił im książę Wilhelm, związany z nimi więzami rodzinnymi.

Kolejne cztery rozdziały opowiadają o walce o władzę, jaką stoczyli synowie Ethelreda z Haroldem, synem Kanuta. W tej wstępnej części dzieła autor przekazuje odbiorcy podstawowe założenia porządkujące narrację. Edward, późniejszy król, nie zdołał objąć władzy. Wilhelm z Poitiers tłumaczy to w ten sposób, że Anglicy bali się zbuntować przeciw Haroldowi, a Edward podjął decyzję o rezygnacji z walki z uwagi na szczupłość swych sił, po czym udał się do Normandii, gdzie mógł bezpiecznie i wygodnie żyć. Brat Edwarda, Alfred, postanowił podjąć walkę i przypłynął do Anglii na czele zebranych sił, aby odzyskać sceptrum paternum - posługując się tym sformułowaniem Wilhelm z Poitiers wskazuje, iż słuszność roszczeń Alfreda wynikała z tego, że był on synem Ethelreda, ostatniego prawowitego króla, a więc prawowitym dziedzicem tronu i każdy, kto występował przeciwko niemu po stronie króla-tyrana, był zdrajcą. Wilhelm z Poitiers opowiada, że Alfred, po przypłynięciu do Anglii, został powitany przez jarla Godwina, który zapewnił go o swojej pomocy i zaprosił na ucztę, po czym wydał podstępnie w ręce ludzi Harolda Zajęczej Stopy. Zgodnie z tą wersją wydarzeń zdrada Godwina spowodowała nie tylko klęskę Alfreda, ale także śmierć jego i jego ludzi. Godwin jest w tej opowieści zdrajcą i bratobójcą, bo nie wahał się zabijać swoich rodaków, służąc królowi - zewnętrznemu uzurpatorowi.

Synem jarla Godwina jest Harold, w późniejszym czasie główny oponent Wilhelma Zdobywcy. W I, 4 autor w apostroficznej wypowiedzi skierowanej do Godwina zarysowuje główny temat swej opowieści, a jednocześnie przedstawia jej dwóch najważniejszych bohaterów ${ }^{29}$. Harold, syn Godwina, i Wilhelm to postaci, których rywalizacja stanowi główny wątek opowiadanej historii. Harold podobny do ojca, wiarołomny i okrutny, jest spadkobiercą Godwina. Wilhelm Zdobywca jest tym, który pomści zdradę i krew wylaną w wyniku haniebnego czynu Godwina. Autor tym samym przyporządkowuje głównym bohaterom role do odegrania, by odbiorca uzyskał klarowny obraz rywalizacji dobra ze złem, dzięki czemu nie może mieć wątpliwości, czyja sprawa jest słuszna. Wilhelm Zdobywca w tej wizji jest kimś, kto naprawia wcześniej wyrządzone zło, dokonuje pomszczenia zdradzonych i okrutnie zamordowanych ludzi.

Dlaczego to Wilhelm Zdobywca ma być tym, do którego należy obowiązek pomszczenia Alfreda i jego ludzi? Wilhelm z Poitiers musiał zmierzyć się z tym problemem i dać odbiorcy odpowiedź nie pozostawiającą wątpliwości. Wedle jego wizji wydarzeń Godwin, zabijając Alfreda i jego ludzi, dopuścił się przelania krwi normańskiej ${ }^{30}$. Choć autor nie wyjaśnia tego zagadnienia szerzej w tym miejscu, to z treści I, I można się dowiedzieć, że matką Alfreda i Edwarda była Emma, normańska księżniczka, córka księcia Ryszarda I. Morderstwo syna

29 GG I, 4, s. 6: Guillelmus vero, gloriosissimus dux, cuius acta venturam aetatem divina opitulatione freti docebimus, vindice gladio feriet iugulum Heraldi, tuae sobolis crudelitate perfidiaque consimillimae.

30 Ibidem: „Fundis traditione tua immeritum sanguinem Normannorum: fundetur sanguis tuorum pari vice ferro Normannorum! 
normańskiej księżniczki i prawowitego następcy tronu Anglii domagało się pomsty - Wilhelm Zdobywca mści się za swego kuzyna i jednocześnie za niesprawiedliwość uczynioną przeciw królestwu Anglii, czym niewątpliwie było morderstwo następcy tronu popełnione w służbie tyrana-agresora. Autor, kreśląc taką wizję, pośrednio dostarcza argumentów uzasadniających to, że w I066 r. Wilhelm Zdobywca był jedynym prawowitym pretendentem do tronu.

W I, 5 Wilhelm z Poitiers kończy wstępną część opowieści, mówiąc o osobie Hardekanuta, następcy Harolda Zajęczej Stopy, syna Kanuta i Emmy. Ponieważ Hardekanut był synem Emmy, zostaje on przedstawiony jako postać pozytywna. Dziejopisarz podkreśla, że nie był on podobny do ojca i brata. Nie cechowało go okrucieństwo, co zawdzięcza matce, a także był przychylny wobec Edwarda. Taki obraz Hardekanuta podkreśla zalety Emmy, kluczowej postaci, łączącej dom normański z władcami anglosaskimi, oraz wprowadza temat objęcia władzy przez Edwarda Wyznawcę.

\section{Objęcie władzy przez Edwarda Wyznawcę i ustanowienie Wilhelma dziedzicem $(\mathrm{I}, 14)$}

Od I, 6 autor przechodzi do głównego wątku, czyli do opowieści o czynach Wilhelma Zdobywcy. Pierwsza z dwóch ksiąg dzieła opowiada o jego działaniach w Normandii przed Io66 r. W jej obrębie dziejopisarz umieścił fragmenty, które nie dotyczą centralnego tematu, a jednocześnie są istotnymi wypowiedziami uzasadniającymi słuszność roszczeń Zdobywcy do tronu Anglii.

Jednym z takich miejsc jest I, I4, gdzie autor opisuje objęcie władzy w Anglii przez Edwarda Wyznawcę oraz opowiada o ustanowieniu Wilhelma dziedzicem korony. Obok wyliczenia zalet Edwarda, które potwierdzają, iż jest on godny tytułu królewskiego, zostaje wyraźnie podkreślone, że uzyskał on ten tytuł dzięki wsparciu księcia Normandii ${ }^{31}$. W tej wizji wydarzeń Wilhelm Zdobywca przywraca słuszny porządek w Anglii okupowanej od wielu lat przez dynastię władców-tyranów. Za jego przyczyną władzę odzyskuje prawowity spadkobierca tronu, jedyny dziedzic korony, syn ostatniego prawdziwego króla. Wilhelm tym samym stoi po stronie dobra - iustitia i aequitas to wartości, którymi się kieruje i których strzeże. Przypisywanie mu takiej roli jest jednym z podstawowych argumentów ideowych leżących u podstaw jego panowania w Anglii.

W drugiej części tego rozdziału dochodzi do przekazania korony.

Edwardus autem, dum grato reputaret affectu quam sumptuosam liberalitatem, quam singularem honorem, quam familiarem dilectionem in Normannia sibi impenderit princeps Guillelmus, tam beneficiis quam linea consanguinitatis longe sibi coniunctior; quinetiam quam studioso eius auxilio in regnum ab exilio sit restitutus, potissimum aliquid atque gratissimum recompensare desiderans more honestorum; coronae quam per eum adeptus est, eum rata donatione haeredem statuere decrevit.

Na jakiej podstawie w opowieści Wilhelma z Poitiers Edward Wyznawca już na początku panowania ustanowił Zdobywcę dziedzicem tronu angielskiego? Dziejopisarz w cytowanym fragmencie posługuje się trzema uzasadnieniami. Po pierwsze, Edward musi wynagrodzić

31 GG I, 14, s. 18: Ipsius [Wilhelma] quoque viribus et consilio Edwardus, Hardechunuti vita finita, tandem in patreno solio coronatus resedit. 
Wilhelmowi to, że on w Normandii obdarzył go miłością, jaką darzą się członkowie jednej rodziny, obdarzył go szczególnym szacunkiem i czcią, a także wielką hojnością. Familiaris dilectio jest szczególnie istotne, bo sugeruje, że w pewnym sensie Wilhelm i Edward byli rodziną ze względu na łączące ich więzi. Autor kontynuuje podkreślanie więzi między oboma bohaterami opowieści w drugiej grupie uzasadnień. Pisze, że wymienione wcześniej łaski i dobrodziejstwa czynią ich bliskimi sobie ludźmi, co znajduje potwierdzenie w tym, że są oni krewnymi. Trzecim elementem jest pomoc, dzięki której Edward mógł powrócić z wygnania i zasiąść na tronie ojca. Wilhelm z Poitiers tak zbudował wizję wydarzeń, że korona noszona przez Edwarda należy do Wilhelma, bo gdyby nie on, Wyznawca nie zostałby królem Anglii. Taka jest wymowa ostatnich słów zacytowanego fragmentu.

Autor dodał do tego obrazu zgodę możnych na ustanowienie Wilhelma dziedzicem, a poselstwo do Normandii miało przekazać wiadomość o podjętej decyzji. Z tym zadaniem wysłany został Robert, arcybiskup Canterbury, zaś jako zakładników na dwór normański oddano syna i wnuka jarla Godwina ${ }^{32}$. Zarówno aprobata wasali Edwarda, jak i pełnienie roli zakładników przez potomków Godwina pełni ważną rolę ideową dla dalszej części opowiadania.

\section{Przysięga Harolda - zjazd w Bonneville (I, 41-46)}

Pod koniec księgi pierwszej autor przerywa narrację o czynach Wilhelma w Normandii, aby powrócić do tematu sukcesji tronu angielskiego. W I, 4I opisane są okoliczności wysłania Harolda Godwinsona na dwór normandzki - miał on złożyć Wilhelmowi przysięgę potwierdzającą oddanie mu władzy w Londynie. Rozdział rozpoczyna się od uzasadnienia tego aktu, a w dalszej części opisana jest podróż Harolda do Normandii.

Wilhelm z Poitiers pisze, że Edward zdecydował o wysłaniu Harolda, ponieważ to on był jego najpotężniejszym wasalem oraz miał wielki autorytet pośród Anglików. W ten sposób Wyznawca chciał zapewnić akceptację wszystkich poddanych dla Wilhelma Zdobywcy jako sukcesora ${ }^{33}$. Wedle słów dziejopisarza Edward, który został opisany jako człowiek prowadzący święte życie, czuł, że zbliża się jego śmierć i że jest już blisko nieba. Obraz świętości Edwarda jest zestawiony z obrazem jego relacji z Wilhelmem - łączyła ich miłość braterska albo nawet taka, jaką ojciec darzy swego potomka ${ }^{34}$. Dlatego też decyzja Edwarda o zapewnieniu sukcesji Wilhelmowi w obliczu bliskiej śmierci nie jest jedynie pragmatycznym aktem wynagradzającym sojusznikowi okazaną pomoc i gwarantującą spokój wewnętrzny w obliczu wygaśnięcia dynastii. Przekazanie władzy Wilhelmowi jawi się w tej wizji dziejów Anglii i Normandii jako owoc świętości Edwarda. Nie miał on potomstwa, gdyż ofiarował Bogu dziewicze życie, a w zamian Bóg obdarzył go Wilhelmem - krewnym, którego Edward pokochał jak brata lub syna. W tej narracji autor pośrednio sugeruje związek pomiędzy świętym wyrzeczeniem się potomstwa przez Edwarda a objęciem władzy przez Wilhelma.

\footnotetext{
32 Synem był Wulfnoth, zmarły w niewoli za panowania Wilhelma Rufusa, wnukiem Hakon, zwolniony przy okazji wizyty Harolda Godwinsona w Normandii; GG, s. 20, przyp. 2.

33 GG I, 41, s. 68: Et eum quidem prudentissime, ut ipsius opes et auctoritas totius Anglicae gentis dissensum coercerent, si rem novare mallent perfidia mobilitate, quanta sese agunt.

34 Ibidem: Per idem fere tempus Edwardus rex Anglorum suo iam statuto haeredi Guillelmo, quem loco germani aut prolis adamabat, graviore quam fuerit cautum pignore cavit. Placuit obitus necessitatem praevenire, cuius horam homo sancta vita ad caelestia tendens, proximam affore meditabatur.
} 
Świętość Edwarda otworzyła drogę do koronacji księcia Normandii na króla Angliii ${ }^{35}$. Ktoś, kto sprzeciwi się sukcesji Wilhelma, będzie nie tylko łamał przysięgę, ale stanie się wręcz wrogiem Opatrzności, burzycielem Bożego planu.

Pozostała część rozdziału I, 4I opowiada o przebiegu podróży Harolda do Normandii. Statek, którym płynął, musiał z powodu niebezpieczeństw na morzu zmienić kurs i dlatego wylądował na wybrzeżu Ponthieu. Tam Harold i jego ludzie zostali wzięci do niewoli przez hrabiego Gwidona. Gdy dowiedział się o tym książę Wilhelm, doprowadził do ich uwolnienia i z wielką hojnością oraz szacunkiem przyjął w Rouen, stolicy swego księstwa.

Kolejny rozdział poświęcony został zjazdowi w Bonneville. Harold złożył tam Wilhelmowi przysięgę wierności, przez co stał się jego wasalem ${ }^{36}$. Autor podkreśla, że ślubował on sancto ritu christianorum - zaakcentowanie chrześcijańskiego charakteru tego aktu tworzy kolejną płaszczyznę delegitymizacji Harolda. Złamanie tej przysięgi jest czynem sprzeciwiającym się zasadom wierności wasalnej, ale także jest to ciężki grzech, który zasługuje na potępienie. Rywalizacja Wilhelma i Harolda w narracji Gesta Guillelmi jest więc czymś więcej niż sporem politycznym, bo jest walką chrześcijańskiego władcy z uzurpatorem będącym wrogiem wspólnoty chrześcijan. Zwycięstwo Wilhelma jest zaprowadzeniem chrześcijańskiego ładu - w omawianym miejscu opowieści autor kolejny raz używa tego uzasadnienia.

Następnie Wilhelm z Poitiers przytacza treść przysięgi, ale jeszcze przed tym zapewnia, że wiedzę czerpał od świadków, uczciwych i prawdomównych ludzi, oraz że Harold sam osobiście wypowiadał słowa przyrzeczenia i robił to dobrowolnie ${ }^{37}$. Autor wyraźnie pragnął jak najmocniej podkreślić wagę tego wydarzenia i wiarygodność swojego opisu. Treści przysięgi poświęcił oddzielny rozdział, w którym dokładnie wyliczył jej poszczególne punkty. Zamiarem autora było, aby pełniła ona ważną rolę w legitymizacji władzy Wilhelma. Harold obiecał być wsparciem dla Wilhelma i współdziałać z nim w wypełnieniu woli Edwarda Wyznawcy ${ }^{3}$. Być może ważniejsze jest to, o czym wspomina autor po wymienieniu punktów przysięgi, a co według niego miało wydarzyć się jeszcze przed jej złożeniem:

Dux ei, iam satelliti suo accepto per manus, ante iusiurandum terras eius cunctumque potentatum dedit petenti. Non enim in longum sperabatur Edwardi aegrotantis vita ${ }^{39}$.

Jest to ważne dopowiedzenie, które potwierdza lenną zależność Harolda od Wilhelma. Dziejopisarzowi zależało, aby fakt ten wybrzmiał dostatecznie mocno. To Wilhelm był dysponentem ziem i tytułów Harolda - Wilhelm jako senior nadał Haroldowi, swemu lennikowi, wszelkie ziemie i godności, a w zamian syn Godwina był zobowiązany wspomagać we wszystkim księcia Normandii, służyć mu radą i w razie potrzeby pomocą zbrojną. Odbiorca

\footnotetext{
35 Marafioti, The King's Body, s. 245.

36 GG I, 42, s. 70: Coadunato ad Bonamvillam consilio, illic Heraldus ei fidelitatem sancto ritu christianorum iuravit.

37 Ibidem: Et sicut veracissimi multaque honestate praeclarissimi homines recitavere, qui tunc affuere testes, in serie summa sacramenti libens ipse haec distinxit.

38 Ibidem: Se in curia domini sui Edwardi regis quandiu superesset ducis Guillelmi vicarium fore; enisurum quanto consilio valeret aut opibus ut Anglica monarchia post Edwardi decessum in eius manu confirmaretur; traditurum interim ipsius militum custodiae castrum Doveram, studio atque sumptu suo communitum; item per diversa loca illius terrae alia castra, ubi voluntas ducis ea firmari iuberet, abunde quoque alimonias daturum custodibus.

39 Ibidem.
} 
tej opowieści nie może mieć żadnych wątpliwości: Wilhelm i Harold nie są równorzędnymi rywalami o tron Anglii, nie są po prostu oponentami politycznymi, których interesy stoją w sprzeczności do siebie. Walka Harolda przeciwko Wilhelmowi nie jest walką dwóch pretendentów do jednego tronu. Jest zdradą, jest złamaniem przysięgi, wystąpieniem przeciw chrześcijańskiemu porządkowi świata.

Rozdziały I, 43-I, 45 opowiadają o wojnie, jaką Wilhelm toczył w Bretanii. Harold wraz ze swymi towarzyszami został zabrany na kampanię wojenną w orszaku księcia Normandii, przez którego został wyposażony w broń i najlepsze konie. Autor dopowiada, że Harold był żądny sławy i chciał wziąć udział w walce, a Wilhelm traktował go quasi contubernalem jak bliskiego przyjaciela, dopuszczając go do swego otoczenia. Za to wyróżnienie Harold miał odpłacić oddaniem i wiernością ${ }^{40}$. Nie można nie dostrzec w tym miejscu dążenia dziejopisarza do pokazania wyższości Wilhelma nad Haroldem. Książę Normandii, widząc, że syn jarla Godwina chce wsławić się bohaterstwem w boju, pozwala mu na wzięcie udziału w kampanii wojennej. Uzbraja go i łaskawie zaprasza do swego orszaku. Jest to obraz, w którym senior obdarza szczególnymi zaszczytami swego wasala, co powinno być zrekompensowane pełnym oddaniem i lojalnością. W trakcie opowiadania o walce ze zbuntowaną Bretanią autor nie wspomina o Haroldzie. Wilhelm z Poitiers ponownie skupia się na nim w rozdziale I, 46.

Dla zrozumienia znaczenia tego rozdziału należy spojrzeć na jego umiejscowienie w całości narracji. W pewien sposób zamyka on opowieść o czynach Wilhelma Zdobywcy przed I066 r. Kolejne rozdziały aż do końca pierwszej księgi (I, 47-59) nie opisują dziejów Wilhelma, są wyrwaną z układu chronologicznego rozbudowaną pochwałą jego przymiotów. Tak więc epizod opisany w I, 46 w sekwencji wydarzeń bezpośrednio poprzedza śmierć Edwarda Wyznawcy i rok Io66. W omawianym rozdziale autor opisuje powrót Harolda do Anglii oraz kieruje do niego wypowiedź niosącą ważne treści na płaszczyźnie ideowej.

Wilhelm z Poitiers podkreśla hojność księcia Normandii względem Harolda. Zdobywca przed tym, jak odesłał swego wasala do Anglii, w dowód szacunku i życzliwości obdarował go licznymi prezentami, a także pozwolił, aby dołączył do niego wnuk Godwina, Hakon, przez co okazał swoje zaufanie ${ }^{41}$. Pozostała część tego rozdziału to oskarżycielskie przemówienie, którego adresatem jest Harold:

Qua mente post haec Guillelmo haereditatem auferre, bellum inferre, ausus es, cui te gentemque tuam sacrosancto iureiurando subiecisti tua et lingua et manu? Coercere debuisti, et perniciosissime concitasti. Infeliciter secundi flatus, qui nigerrimis velis tuis aspiraverunt redeuntibus. Impie clemens pontus qui vehentem te hominem teterrimum ad littus provehi passus est. Sinistre placida statio fuit quae recepit te naufragium miserrimum patriae afferentem.

W jaki sposób Wilhelm z Poitiers nazywa starania Harolda o władzę w Anglii? Według niego jest to haereditatem auferre, bellum inferre - zagarnianie dziedzictwa i wywoływanie

40 GG I, 43, s. 70: Deinde, quia ferocem et novi nominis cupidum novit, ipsum et qui venerant cum ipso armis militaribus et equis delectissimis instructos secum in bellum Britannicum duxit; hospitem atque legatum quasi contubernalem habens ut eo quoque honore quodam sibi magis fidum et obnoxium faceret.

41 GG I, 46, s. 76: Receptus in sua, precarum hospitem Heraldum apud se post moratum aliquandiu, donis onustum omisit; digne utroque et cuius iussu et pro cuius honore ampliando venerat. Qui etiam fratruelis eius, alter obses, cum ipso redux propter ipsum redditus est. Na temat Hakona patrz: przyp. 32. 
wojny. Anglia jest haereditas - dziedzictwem Wilhelma, ofiarowanym mu przez Edwarda Wyznawcę. Nie jest krajem, który może być obiektem agresji ze strony księcia Normandii. Taką perspektywę odrzuca Wilhelm z Poitiers. Zależało mu, aby przedstawić to wydarzenie jako rozpoczęcie panowania w królestwie, które już należało do Wilhelma Zdobywcy. Harold swoimi działaniami wywołuje wojnę, on jest agresorem. Na mocy jego przysięgi Wilhelmowi podlegał zarówno on sam, jak i cały jego naród. Harold nie jest obrońcą, rywalem Wilhelma, ale buntownikiem przeciw legalnej władzy. Autor podkreśla przy tym, że Harold nie działa dla dobra swojej ojczyzny, lecz poprzez bunt sprowadza na nią nieszczęście.

\section{Nielegalna koronacja Harolda}

Księga druga rozpoczyna się opisem nielegalnej koronacji Harolda, przeprowadzonej krótko po śmierci Edwarda Wyznawcy na początku stycznia Io66 r. Autor wykorzystuje ten moment historii do delegitymizacji Harolda jako króla Anglii.

Verus namque rumor insperato venit, Anglicam terram rege Edwardo orbatam esse et eius corona Heraldum ornatum. Nec sustinuit vesanus Anglus quid electio publica statueret consulere; sed in die lugubri quo optimus ille humatus est, cum gens universa plangeret, periurus regium solium cum plausu occupavit, quibusdam iniquis faventibus. Ordinatus est non sancta consecratione Stigandi, iusto zelo apostolici et anathemate ministerio sacerdotum privati ${ }^{42}$.

W wizji wydarzeń, jaką skonstruował Wilhelm z Poitiers, Harold nie został koronowany na króla, akt ten był bowiem nielegalny. Kolejny raz zostaje podkreślone, że Wilhelm Zdobywca nie występuje przeciwko innemu władcy, ale sprawiedliwie karze buntownika, uzurpatora i krzywoprzysięzcę. Autor wyraźnie stara się podkreślić, że koronacja Harolda odbyła się bez akceptacji angielskiej elity. Przeciwnik Wilhelma starał się pośpiesznie przechwycić władzę, która mu się nie należała i dlatego zdecydował się zasiąść na tronie, gdy trwała jeszcze żałoba po zmarłym królu Edwardzie. Jak wspomina autor, popierało go tylko kilku niegodziwych ludzi, co oczywiście ma na celu dodatkowo pokazać brak szerokiego poparcia. Ważnym elementem opisu jest wskazanie na nieważność namaszczenia. Według opisu Wilhelma z Poitiers tego aktu dokonał Stigand, biskup ekskomunikowany decyzją Stolicy Apostolskiej43.

\section{Wydarzenia przed bitwą}

Jeszcze w tym samym rozdziale autor opowiada o tym, w jakich okolicznościach Wilhelm podjął decyzję o wyruszeniu z armią do Anglii. W przeciwieństwie do Harolda, który działał niemal potajemnie, popierany przez garstkę niegodziwców, Wilhelm spotkał się z elitą Normandii i uzyskał pełną akceptację dla swoich zamierzeń. Zostaje przy tym po

42 GG II, 1, s. 100.

43 G. Garnett, Coronation and Propaganda: Some Implications of the Norman Claim to the Throne of England in 1066, „Transactions of the Royal Historical Society”, 36/1986, s. 98; Marafioti, The King's Body, s. 114 i 117 przyp. 152. 
raz kolejny nakreślona wizja konfliktu: Wilhelm zdecydował, że zbrojnie ukarze winnych bezprawia i upomni się o jemu należne dziedzictwo ${ }^{44}$.

Na tym etapie narracji ważne jest, w jaki sposób autor poprzedza rozpoczęcie opisywania inwazji. Poza przedstawieniem spraw organizacyjnych związanych z przygotowywaniem armii, Wilhelm z Poitiers nakierowuje uwagę odbiorcy na pewne wydarzenia, których opis ma na celu pokazanie słuszności działań Zdobywcy. Na pewno taki ma cel szeroka wypowiedź o poparciu, jakiego księciu Normandii udzielił biskup Rzymu. Dziejopisarz podkreśla, że Wilhelm Zdobywca prosił papieża o duchowe wsparcie - wysłał do niego poselstwo, w którym wyjaśnił swoje roszczenia do tronu Anglii. W odpowiedzi Aleksander II przekazał mu swą chorągiew, która stanowiła znak pełnego poparcia ze strony następcy św. Piotra ${ }^{45}$. Przychylność papieża w zestawieniu z namaszczeniem Harolda przez ekskomunikowanego biskupa jest kolejnym elementem narracji, który sytuuje Wilhelma po stronie dobra, po stronie cywilizowanego świata, a jego rywala po stronie zła i sił wrogich całej chrześcijańskiej wspólnocie wierzących. Uzasadnianie władzy Wilhelma w Anglii wkracza na płaszczyznę religijną. Skoro Harold współdziała ze schizmatyckim biskupem, to obowiązkiem każdego chrześcijanina jest dołączyć do księcia Normandii, aby przywrócić właściwy, prawdziwie chrześcijański ład w Londynie. W opisie Wilhelma z Poitiers wyprawa Zdobywcy nabiera cech wojny religijnej. Co prawda nie wspomina, że jej uczestnicy uzyskują odpuszczenie win, ale otrzymanie papieskiej chorągwi było bardzo wymowne, a niedługo później wiązało się z symboliką ruchu krucjatowego.

W analizowanej wizji wydarzeń Wilhelm Zdobywca był popierany również przez cesarza Henryka IV ${ }^{46}$, z którym łączyła go przyjaźń ${ }^{47}$. Ta informacja wzmacnia wrażenie szerokiego poparcia dla roszczeń Wilhelma - po jego stronie stoi nie tylko cała elita Normandii, ale także dwaj najważniejsi władcy w Europie, papież i cesarz, są jego sojusznikami i wyrażają akceptację dla jego działań.

W rozdziale II, 5 autor przytacza przemowę Wilhelma skierowaną do rycerstwa normańskiego, które traciło wiarę w możliwość zwycięstwa nad Haroldem ${ }^{48}$. Wilhelm z Poitiers oprócz pokazania przy tej okazji odwagi Zdobywcy i jego cech przywódczych przywołuje argumenty ideowe uzasadniające słuszność działań księcia Normandii. Dziejopisarz włożył w usta Zdobywcy słowa podnoszące na duchu swych wasali i pomniejszające znaczenie potęgi Harolda. Zgodnie z nimi Normanowie mogą ufać w swoje siły i nie powinni się bać, gdyż walczą w słusznej sprawie ${ }^{49}$. Harold broni królestwa, które zagarnął dla siebie w sposób nielegalny. Broni tego, co zdobył poprzez przestępstwo. Wilhelm wiedzie Normanów do walki o to, co się im należy - trzeba tutaj podkreślić, że autor używa liczby mnogiej w odniesieniu

\footnotetext{
44 GG II, 1, s. 100: Dux Guillelmus habita cum suis consultatione armis iniuriam ulcisci, armis haereditatem reposcere decrevit.

45 GG II, 3, s. 104: Huius apostolici favorem petens dux, intimato negotio quod agitabat, vexillum accepit eius benignitate velut suffragium sancti Petri, quo primo confidentius ac tutius invaderet adversarium.

46 Henryk IV był cesarzem od 1084 r., a rządził od 1056 r.

47 GG II, 3, s. 104: Et Romanorum imperatori Henrico, Henrici imperatoris filio, nepoti imperatoris Chuonradi, noviter iunctus fuit in amicitia, cuius edicto in quemlibet hostem Germania ei, si postularet, veniret adiutrix.

48 GG II, 4, s. 106: Stupentes vero grande promissum primores Normannorum, multi diffidentiam suam non reticent. Amplificant oratione, quam desperatio dictavit, opes Heraldi, suas diminuunt.

49 GG II, 5, s. 108: Praeterea ne rapinam amittat ille pugnabit; nos quae dono accepimus, beneficiis comparavimus, requirimus. Quae partis nostrae prima fiducia periculum omne depellens, laetissimum triumphum nobis, summum decus, praeclarissimum nomen dabit.
} 
do wspólnoty rycerstwa normańskiego, przez co stwarza opozycję „my - on”"50. Harold jest osamotniony, a Wilhelm walczy w interesie wspólnoty rycerstwa normańskiego - szerokie poparcie dla jego działań oraz występowanie w imieniu zbiorowości mają dowodzić słuszności jego roszczeń i zamierzeń.

Dziejopisarz podsumowuje przemowę Wilhelma następującymi słowami:

Etenim constabat viro catholico ac sapienti, quod omnipotentia Dei, nihil volens iniquum, iustam causam cadere non sineret, praesertim consideranti sese, qui non tantum ditionem suam et gloriam augere, quantum ritus christianos partibus in illis corrigere intendit ${ }^{51}$.

To zdanie kończy rozdział II, 5. Dwa następne opisują już bezpośrednie przygotowanie do wyjścia w morze, oczekiwanie na pomyślny wiatr oraz podróż do wybrzeży Anglii, w związku z czym należy zwrócić szczególną uwagę na ostatnie słowa rozdziału II, 5. Autor postanowił jeszcze przed opisem wydarzeń związanych z rozpoczynaniem inwazji odwołać się ponownie do sfery nadprzyrodzonej, by w ten sposób wzmocnić argumentację ideową roszczeń Wilhelma do tronu Anglii. Przekonuje on, że to sam Bóg stoi po stronie księcia Normandii, którego upomnienie się o sukcesję po królu Edwardzie to iusta causa, natomiast postępowanie Harolda nazwane zostaje słowem iniquitas. Odbiorca upewnia się, że Bóg wspiera Normanów, ponieważ Wilhelm walczy w imię Boże. Jego celem nie jest jedynie zdobycie władzy i chwały, ale także to, by przyczynić się do zbawienia żyjących tam ludzi poprzez pomoc w reformie angielskiego Kościoła.

$\mathrm{Na}$ tej podstawie można wnioskować, że argumentacja na płaszczyźnie religijnej była istotnym elementem zbioru uzasadnień dla działań Wilhelma Zdobywcy. Poparcie papieża, walka dla dobra Kościoła, przychylność Boga, a także pokazywanie Harolda jako wroga chrześcijan służyły autorowi do upewnienia odbiorcy, że Wilhelm w pełni słusznie i legalnie objął tron Anglii.

W rozdziale II, 8 Wilhelm z Poitiers opisuje zejście na ląd armii normandzkiej i wspomina, że Harold nie wydał im wówczas bitwy, ponieważ musiał wyruszyć na północ, by walczyć z drugą wrogą mu armią króla Norwegii, wspieranego przez Tostiga, brata Harolda. Uwaga odbiorcy nie jest skierowana w tym miejscu na przebieg działań wojennych. Autor wzmacnia obraz Harolda jako osoby osamotnionej, nie mającej poparcia, opuszczonej nawet przez najbliższych. Przeciwko Haroldowi zwrócił się rodzony brat, rozjuszony doznanymi od niego krzywdami. Również jego siostra, Edyta, wdowa po królu Edwardzie Wyznawcy ${ }^{52}$, była mu wroga. Uzasadniając wrogość Edyty autor charakteryzuje dwóch oponentów: Harold był rozpustnikiem, mordercą i złodziejem, przeciwnikiem dobra i sprawiedliwości. Edyta popierała roszczenia Wilhelma do korony angielskiej ze względu na to, że jej mąż, król Edward, usynowił go i ustanowił dziedzicem oraz dlatego, że był on mądry, sprawiedliwy i silny ${ }^{53}$.

\footnotetext{
50 Liczba mnoga nie pełni w tym miejscu funkcji ,pluralis maiestatis”.

51 GG II, 5, s. 108.

52 P. Stafford, Queen Emma and queen Edith, Oxford 1997.

53 GG II, 8, s. 114: Quem germana quoque illi moribus absimillima, cum armis non valeret, votis impugnabat et consilio, luxuria foedum, truculentum homicidiam, divite rapina superbum, adversarium aequi et boni. Voluit autem virilis prudentiae femina intelligens honesta quaelibet ac vita colens, Guillelmum Anglis dominari, quem Edwardi regis mariti sui adoptio, filii loco, sibi succedere statuit: sapientem, iustum, fortem.
} 


\section{Wymiana poselstw}

Rozdziały II, II-I3 relacjonują wymianę poselstw pomiędzy rywalizującymi wodzami. Autor za pomocą opisu tych wydarzeń ponownie, w rozbudowany sposób, przytacza argumentację wspierającą roszczenia Wilhelma. Można w tym dostrzec dążenie do potwierdzenia słuszności działań księcia Normandii na krótko przed kulminacyjnym momentem narracji, jakim jest opis bitwy pod Hastings.

Treścią rozdziału II, II jest poselstwo wysłane przez Harolda do Wilhelma. Syn Godwina posłał mnicha, aby wyłożyć racje uzasadniające legalność jego władzy i skłonić Zdobywcę do powrotu do domu ${ }^{54}$. Głównym argumentem jest to, że król Edward na łożu śmierci oddał królestwo Haroldowi, a w Anglii istnieje zwyczaj od czasów św. Augustyna ${ }^{55}$, że donację uczynioną na łożu śmierci uznaje się za ważną i wiążącą. W rozdziale II, I2 autor przytacza mowę Wilhelma, którą ten skierował do mnicha mającego powtórzyć ją Haroldowi. W tej przemowie autor przypisuje Wilhelmowi słowa podsumowujące i streszczające zbiór uzasadnień dla swych roszczeń do objęcia tronu Anglii.

Stosunkowo długa przemowa, którą autor przypisał Zdobywcy, zaczyna się od ogólnego zapewnienia, iż to po jego stronie jest słuszność i sprawiedliwośćs ${ }^{6}$. Następnie dokładnie uzasadniona zostaje legalność i prawomocność ustanowienia Wilhelma sukcesorem przez Edwarda $^{57}-\mathrm{w}$ tym miejscu autor obok wspomnienia dobrodziejstw, jakie Wilhelm wyświadczył Edwardowi, akcentuje, że Wilhelm i Edward należeli do jednego rodu i Zdobywcę uznano za najwybitniejszego jego przedstawiciela.

Kolejnym elementem argumentacji jest fakt zaakceptowania decyzji króla Edwarda przez możnych angielskich. Przyrzekli oni, że nie będą oponować przeciw koronacji Wilhelma ${ }^{58}$. Jako możni, którzy poparli ustanowienie dziedzicem księcia Normandii i pod przysięgą zobowiązali się do zaniechania wszelkich wrogich mu działań, wymienione są cztery postaci, pośród nich Godwin - ojciec Harolda oraz Stigand - arcybiskup, który dokonał bezprawnej koronacji syna Godwina.

Wreszcie uwaga zostaje skierowana na samego Harolda. Przybył on osobiście do Normandii, gdzie złożył Wilhelmowi hołd wasalny, przysiągł być mu lojalnym oraz potwierdził prawomocność uczynienia Zdobywcy sukcesorem tronu Anglii, co ma być ostatecznym potwierdzeniem, że syn Godwina dopuścił się bezprawia, obejmując władzę po śmierci Wyznawcy ${ }^{59}$. Na koniec Wilhelm zaapelował do przeciwnika, aby ich spór został rozstrzy-

\footnotetext{
54 GG II, 11, s. 118: Novit autem iure suum esse regnum idem, eiusdem regis domini sui dono in extremis illius sibi concessum. Etenim ab eo tempore quo beatus Augustinus in hanc venit regionem, communem gentis huius fuisse consuetudinem, donationem quam in ultimo fine suo quis fecerit, eam ratam haberi.

55 Św. Augustyn, pierwszy biskup Canterbury (+604/605).

56 GG II, 12, s. 120: Non temere neque iniuste, sed consulto et aequitatis ductu in hanc terram transvectus sum.

57 Ibidem: Cuius me haeredem, ut Heraldus ipse fatetur, statuit dominus meus et consanguineus rex Edwardus, ob maximos honores et plurima beneficia quae illi atque fratri suo, necnon hominibus eorum, ego et maiores mei impendimus; et quoniam omnium, qui genus suum attingerent, me credebat excellentissimum, qui optime valerem vel ei, quamdiu viveret, subvenire, vel posteaquam decederet regnum gubernare.

58 Ibidem: Sane neque id absque suorum optimatum consensu, verum consilio Stigandi archiepiscopi, Godwini comitis, Leurici comitis, Sigardi comitis, qui etiam iureiurando suis manibus confirmaverunt, quod post Edwardi decessum me reciperent dominum, nec ullatenus peterent in vita illius patriam hanc ullo impedimento contra me occupari.

59 Ibidem: Postremo Heraldum ipsum in Normanniam transmisit, ut quod pater eius atque caeteri supranominari hic mihi iuravere absenti, is ibi praesens iuraret praesenti. Qui dum pergeret ad me, in periculum captionis incidit,
} 
gnięty przed sądem, dzięki czemu nie zostanie przelana krew Anglików i Normanów. Autor, celem wzmocnienia przekazu, podkreśla, że Wilhelm był pewny swoich racji. Odbiorcę upewnia o tym fakt, że Zdobywca po wezwaniu Harolda na sąd wyraża gotowość, by stanąć do pojedynku ${ }^{60}$.

Następnie Wilhelm z Poitiers do tej obszernej wypowiedzi, jaką włożył w usta Zdobywcy, dodaje akapit, w którym komentuje wyłożone wcześniej argumenty. Zwraca się bezpośrednio do odbiorcy i podsumowuje, że obfita argumentacja przedstawiona przez księcia Normandii niszczy uzasadnienia zaprezentowane przez Harolda. Podkreśla też, że Zdobywca chciał uniknąć walki zbrojnej, co stawia Harolda w roli agresora i burzyciela pokoju ${ }^{6 .}$. W ten sposób autor narracji odkrywa swoje motywy - jego celem było zestawienie argumentów obu stron i wykazanie, że słuszność jest po stronie Wilhelma Zdobywcy. Do tego służy rozbudowana opowieść o wymianie poselstw.

Sceną zamykającą tę opowieść jest przybycie mnicha niosącego odpowiedź Wilhelma do Harolda. Harold, usłyszawszy treść poselstwa, jak przekazują Gesta Guillelmi, zbladł ze zdumienia i długo milczał, jakby stał się niemową ${ }^{62}$. Reakcja Harolda wyraźnie kontrastuje z postawą Wilhelma. Syn Godwina zamilkł, nie potrafił uzasadnić swoich racji, bał się stanąć przed sądem, wolał doprowadzić do walnej bitwy - nie był też w stanie się wycofać, uznać swoich win, ponieważ do konfrontacji pchała go żądza władzy. Wilhelm natomiast jest całkowicie pewny swego i proponuje sąd lub pojedynek. Autor celowo bardzo mocno podkreśla tę różnicę, ponieważ pełni ona istotną rolę w legitymizacji władzy Zdobywcy ${ }^{63}$.

\section{Bitwa}

Opis bitwy pod Hastings jest kulminacyjnym momentem narracji. Opowieść o ostatecznym starciu Wilhelma z Haroldem zajmuje około ośmiu rozdziałów (II, I6-23), które skupiają się głównie na ukazaniu decydującej roli księcia Normandii na polu bitwy, a także jego waleczności, odwagi, cech przywódczych. W II, I6 Wilhelm ustawia się w środku szyku bitewnego, by dowodzić. W II, I8 osobiście powstrzymuje przed ucieczką łamiące się normańskie szeregi, przemawia do rycerzy i skutecznie zachęca ich do walki, co decyduje

unde mea eum prudentia ac fortitudine eripui. Se mihi per manus suas dedit, sua manu securitatem mihi de regno Anglico firmavit.

60 Ibidem: Praesto ego sum ad agendum causam contra illum in iudicio, sive placet illi iuxta ius Normannorum, sive potius Anglorum. Si secundum aequitatis veritatem decreverint Normanni aut Angli, quod ille regnum hoc iure debeat possidere, eum pace possideat. Si vero mihi iustitiae debito reddendum esse consenserint, mihi dimittat. At si conditionem hanc repudiaverit, non duco iustum ut homines mei vel sui concidant praeliando, quorum in lite nostra culpa nulla est. Ecce paratus ego sum capite meo contra caput illius asserere, quod mihi potius quam illi iure cedat regnum Anglicum.

61 Ibidem: Rationum namque copia, sicut liquet attento, quas infirmare nec valeret eloquentiae romanae maximus author Tullius, Heraldi rationem destruxit. Denique iudicium, quod iura gentium definirent, accipere praesto fuit. Anglos inimicos mori ob litem suam noluit; singulari certamine proprio capite causam determinare voluit.

62 GG II, 13, s. 122: Ut ergo mandata eadem Heraldo appropinquanti per monachum sunt relata, stupore expalluit, atque diu ut elinguis obticuit.

63 Ibidem: Rogitanti autem responsum legato semel et iterum, primo respondit: "Pergimus continenter", secundo: "Pergimus ad pretium". Instabat legatus ut aliud responderetur, repetens: non interitum exercituum, sed singulare certamen Normanno duci placere. Nam vir strenuus et bonus iustum aliquid ac laetum renuntiare, nec multos occumbere volebat; Heraldi caput, pro quo minor fortitudo, aequitas nulla staret, casurum confidens. Tum levato Heraldus in caelum vultu ait: "Dominus inter me et Guillelmum hodie quod iustum est decernat". Regnandi siquidem cupidine caecatus, simul ob trepidationem oblitus iniuriae, conscientiam in ruinam sui rectum iudicem optavit. 
o ostatecznym zwycięstwie. Jednak w toku opowiadania o przebiegu bitwy autor stara się również pokazać, że to po stronie Normanów jest słuszność i sprawiedliwość.

Rozdział II, I6, który otwiera opis bitwy, rozpoczyna się wzmianką, że na przedzie linii normańskich umieszczono papieską chorągiew ${ }^{64}$. Autor w kulminacyjnym momencie opowieści, aby podkreślić, że wojsko z Normandii walczyło po słusznej stronie, odwołuje się do poparcia udzielonego przez papieża, czym przypomina o całym zbiorze uzasadnień należących do sfery religijnej - jakimi były walka dla dobra Kościoła w Anglii i sytuowanie Harolda w opozycji do wspólnoty chrześcijan.

Wilhelm z Poitiers, dążąc do pokazania słuszności działań księcia Normandii, wyjaśnił odbiorcy, dlaczego po stronie Harolda, pomimo jego krzywoprzysięstwa i nieprawego objęcia władzy, walczyły tak liczne wojska. Według niego tylko część z nich popierała Harolda, większość walczyła po jego stronie ze względu na chęć obrony swego kraju, nie zważając na to, że nie walczą po słusznej stronie sporu ${ }^{65}$.

Na początku rozdziału II, I7, który opisuje przebieg walki, autor umieszcza ciekawą wypowiedź, krótką, tak jak pozostałe wzmianki odnoszące się do problemu legitymizacji w toku opowieści o przebiegu bitwy, ale obrazową i podsumowującą charakter konfliktu Wilhelma i Harolda:

Normannorum alacris audacia pugnae principium dedit. Taliter cum oratores in iudicio litem agunt de rapina, prior ferit dictione qui crimen intendit ${ }^{66}$.

Poprzez użycie obrazu sprawy sądowej autor kolejny raz przypisuje stronom konfliktu odpowiednie role. Wilhelm jest oskarżycielem - kimś, kto dochodzi swych praw, Harold zaś jest sprawcą rabunku, winnym, który oczekuje na wyrok. Ta wypowiedź zdradza również nastawienie autora wobec wyzwania stworzenia narracji o wyprawie Wilhelma do Anglii i objęciu tamtejszego tronu. Opowieść o konkretnych wydarzeniach traktował on jako konfrontację dwóch racji, spór dwóch osób, który rozstrzyga się nie tyle siłą armii na polu bitwy, ale siłą argumentów na polu ideowym.

Problem legitymizacji władzy autor umieścił w centrum kulminacyjnego momentu narracji. Gdy normańskie szeregi zaczynają słabnąć i rezygnować z walki, Wilhelm osobiście je powstrzymuje przed ucieczką i dodaje otuchy, rusza odważnie na wroga, a za jego przykładem idą podniesieni na duchu Normanowie, którzy odnoszą w końcu zwycięstwo:

His dictis receperunt animos. Primus ipse procurrit fulminans ense, stravit adversam gentem, quae sibi, regi suo, rebellans commeruit mortem $^{67}$.

Wilhelm z Poitiers streszcza wizję konfliktu w kluczowym momencie opowiadania. W tej wizji Wilhelm Zdobywca j e s t królem Anglii. Nie dokonuje on podboju, ale tłumi bunt. Dlatego też jego oponent i popierający go ludzie nie mogą odnieść zwycięstwa - powodem sukcesu księcia Normandii jest słuszność i legalność jego roszczeń i działań. Bitwa

\footnotetext{
64 GG II, 16, s. 126: Hac autem commodissima ordinatione progreditur, vexillo praevio quod apostolicus transmiserat.

65 Ibidem: Studium pars Heraldo, cuncti patriae praestabant, quam contra extraneos tametsi non iuste, defensare volebant.

66 GG II, 17, s. 128.

67 GG II, 18, s. 130 .
} 
została wygrana, bo po stronie Wilhelma były iustitia i aequitas. Autor podkreśla słuszność wygranej Zdobywcy ${ }^{68}$.

Gdy kończy się opis bitwy, uwaga odbiorcy zostaje skierowana na osobę Harolda. W rozdziale II, 25 autor pisze, że Wilhelm przechadzał się po polu bitewnym z żalem, że z powodu tyrana straciło życie tylu ludzi. Odkryte zostają zwłoki Harolda, które następnie pochowano w bezimiennym grobie, na niepoświęconej ziemi morskiego wybrzeża ${ }^{69}$. W dalszej części tekstu autor formułuje wypowiedź, której adresatem jest Harold. Powtarza w niej argumenty delegitymizujące jego władzę. Przywołuje zarzut bratobójstwa wskazując, że był on oszalały z powodu żądzy władzy, przez co nie wahał się doprowadzić swojej ojczyzny do klęski. Autor podkreśla, że Harold w rzeczywistości nie był królem, gdyż objął władzę, łamiąc przysięgę oraz kierując się pychą - to unieważniało jego koronację. Ostatecznym argumentem potwierdzającym nielegalność władzy Harolda jest porażka w bitwie ${ }^{70}$.

\section{Objęcia władzy przez Wilhelma}

Opis objęcia przez Wilhelma należnej mu władzy w Anglii zajmuje rozdziały II, 28-30. Anglicy początkowo obwołują królem Edgara Aethelinga, jednak gdy wojsko normańskie zaczyna niszczyć Londyn, stają się skłonni do oddania władzy Wilhelmowi. Ten pojawia się w pobliżu miasta, a arcybiskup Stigand oraz elita miejska oddają mu Londyn i proszą, aby przyjął koronę królewską ${ }^{71}$. Wilhelm jednak najpierw woli naradzić się ze swoim otoczeniem. Czeka, ponieważ nie chce sprowokować Anglików do powstania, a jego celem nadrzędnym jest utrzymanie pokoju. Woli również poczekać z koronacją na swą małżonkę, Matyldę, respektując w ten sposób świętość więzi małżeńskiej. W ten sposób w oczach odbiorcy jest dobrym i rozsądnym władcą oraz pobożnym chrześcijaninem. Autor zwraca uwagę, że Wilhelm nie był oślepiony żądzą władzy - wyraźnie kontrastuje to z postawą Harolda ${ }^{72}$. W dalszej części rozdziału II, 29 pojawia się postać Emeryka z Akwitanii, wicehrabiego Thouars, który wychwala Wilhelma za to, że radzi się on swych wasali i zachęca elitę normańską, aby szybko udzielić pełnego poparcia dla jego koronacji. Jak pisze autor, Wilhelm ostrożnie rozważył wszelkie racje i w końcu zdecydował się na rozpoczęcie przygotowań do koronacji.

Poszczególne elementy opisu uroczystości koronacji Wilhelma pełnią istotną rolę dla legitymizacji jego władzy. Koronacja Wilhelma jest przeciwieństwem koronacji Harolda opisanej w rozdziale II, $\mathrm{I}^{73}$. Harold został namaszczony przez ekskomunikowanego biskupa i objęcie przez niego władzy popierała jedynie garstka niegodziwych osób, inni w tym

\footnotetext{
68 GG II, 22, s. 136: Proelium quo tam fortiter quam iuste vicit.

69 Szeroko na ten temat Marafioti, The King's Body, s. 232-240.

70 GG II, 25, s. 140: Corruere solent qui summam in mundo potestatem summam beatitudinem putant; et ut maxime beati sint, rapiunt eam, raptam vi bellica retinere nituntur. Atqui tu fraterno sanguine maduisti, ne fratris magnitudo te faceret minus potentem. Ruisti dein furiosus in alterum conflictum, ut adiutus patriae parricidio regale decus non amitteres. Traxit igitur te clades contracta per te. Ecce non fulges in corona quam perfide invasisti; non resides in solio quod superbe ascendisti. Arguunt extrema tua quam recte sublimatus fueris Edwardi dono in ipsius fine.

71 GG II, 28, s. 146.

72 GG II, 29, s. 148: Profecto non illi dominabatur regnandi libido, sanctum esse intellexerat sancteque diligebat coniugii pignus.

73 GG II, 1, s. 100.
} 
czasie jeszcze celebrowali żałobę po śmierci Edwarda Wyznawcy. Sam fakt objęcia władzy w pośpiechu, w czasie żałoby po zmarłym poprzedniku w pewien sposób stanowiło wystąpienie przeciwko niemu, gdyż tym samym nie oddano Edwardowi należytej czci.

Natomiast poparcie dla objęcia władzy przez Wilhelma wyrazili Anglicy i Normanowie $^{74}$. W narracji Wilhelma $\mathrm{z}$ Poiteirs zostaje podkreślone, że namaszczenia i koronacji Zdobywcy dokonał arcybiskup Jorku, który został określony sformułowaniami aequitatem amans, sapiens, bonus ${ }^{75}$. Nowy król Anglii, Wilhelm, wstąpił na tron w obecności wielu opatów i prałatów. Ceremonia odbyła się w londyńskim Opactwie Westminsterskim, gdzie pochowany został Edward Wyznawca - w ten sposób pokazano, że Wilhelm jest sukcesorem Edwarda, a Harold nie jest zaliczony w poczet królów Anglii.

\section{Podsumowanie}

Autor podsumowuje uroczystość objęcia władzy przez Zdobywcę poprzez krótkie streszczenie argumentacji ideowej uzasadniającej jego władzę:

Nec minus insignia regum decuerunt personam eius, quam ad regimen idoneae extiterunt virtutes eius. Cuius liberi atque nepotes iusta successione praesidebunt Anglicae terrae, quam et hereditaria delegatione sacramentis Anglorum firmata, et iure belli ipse possedit: coronatus tali eorundem consensu, vel potius appetitu eiusdem gentis primatum. Et si ratio sanguinis poscitur, pernotum est quam proxima consanguinitate regem Edwardum attigerit filius Rodberti, cuius amita Ricardi secundi soror, filia primi, Emma, genitrix fuit Edwardi ${ }^{76}$.

A zatem Wilhelm ma prawo objąć władzę w Anglii ze względu na swoje zalety osobiste i z powodu wyznaczenia go na dziedzica, co zostało potwierdzone przysięgą Anglików, oraz dlatego, że podbił Anglię siłą swej armii. Dodatkowo jego koronacja została zaakceptowana przez angielską elitę. $\mathrm{Na}$ koniec autor przypomina powiązania rodzinne łączące Edwarda Wyznawcę i Wilhelma, co ma potwierdzać legalność ustanowienia go sukcesorem.

Następnie autor przechodzi do opisu rozdawania bogactw ze skarbca Harolda. W tej narracji nowy król wykazuje się szczodrością, obdarza dobrami klasztory i kościoły, które modliły się o jego zwycięstwo i świętują obalenie tyrana oraz koronację prawowitego króla. Szczególne miejsce pośród nich zajmuje Bazylika św. Piotra. Odbiorca ma odnosić wrażenie, że cały świat chrześcijański popierał Wilhelma i stał po jego stronie na czele z głową Kościoła, biskupem Rzymu.

Gesta Guillelmi Wilhelma z Poitiers są utworem, którego analiza pod kątem problemu legitymizowania władzy dostarcza obfitego plonu badawczego. Autor w dużym stopniu ukształtował opowieść o dziejach Wilhelma Zdobywcy, aby w przekonujący sposób pokazać słuszność jego roszczeń do tronu Anglii. Narracja o czynach księcia Normandii przeplatana

\footnotetext{
74 GG II, 30, s. 150: Protestati sunt hilarem consensum universi minime haesitantes, ac si caelitus una mente data unaque voce. Anglorum voluntati quam facillime Normanni consonuerunt, sermocinato ad eos ac senteniam percunctato Constantiniensi.

75 Autor dodaje, że Wilhelm odrzucił osobę Stiganda ze względu na ciążące na nim kary kościelne - GG II, 30, s. 150: Repudiavit eum consecrari a Stigando Cantuariensi, quem per apostolici iustum zelum anathemate reprobatum didicerat.

76 Ibidem.
} 
jest scenami, które autor tak skonstruował, aby wyłożyć argumentację wspierającą politykę Zdobywcy. W tym celu zwraca się niekiedy bezpośrednio do odbiorcy, komentując opisywane wydarzenia, aby jednoznacznie ocenić bohaterów opowiadania. Wilhelm z Poitiers uzasadnia objęcie władzy w Anglii przez Zdobywcę na płaszczyznach: prawnej, moralnej i religijnej.

\section{The Legitimization of the Rule in William of Poitiers' Gesta Guillelmi Summary}

The aim of the article is to analyse first medieval biography of William the Conqueror in order to explain the issue of legitimization of the Norman rule in England. In the introduction I present the author of Gesta Guillelmi and his work. Main part of the article contains detailed explanatory narrative's elements used by author to provide ideological justifications for William the Conqueror's rule in London.

Keywords: Legitimization, William the Conqueror, England, Normandy, Battle of Hastings

Nota o Autorze: dr Bartlomiej Dźwigala, adiunkt w katedrze historii średniowiecznej Instytutu Nauk Historycznych UKSW. Pracę doktorską przygotowaną pod opieką dr. hab. Marka K. Barańskiego pt. Sukcesja i inauguracja władzy w tacińskiej Jerozolimie. Studium nad narracjami opisujacymi obejmowanie tronu przez nowego wtadce w poczatkowym okresie istnienia Królestwa Jerozolimskiego w latach I099-III8 obronił w 2015 r. na Wydziale Nauk Historycznych i Społecznych UKSW. Magisterium w INH UKSW (20II) oraz w Instytucie Filologii Klasycznej UW (20I4). Zainteresowania badawcze: dzieje wypraw krzyżowych i państw łacińskich w Syrii i Palestynie, problem legitymizacji władzy, łacińska średniowieczna literatura historiograficzna. 